Original Research

\title{
Potential Impacts of a Waste Reception Facility on Stable Isotope Composition of Zooplankton and Particulate Organic Matter in the Dardanelles
}

\author{
Sinan Uzundumlu*, Yesim Buyukates, A. Suat Ateş \\ Çanakkale Onsekiz Mart University, Marine Science and Technology Faculty, Turkey
}

Received: 8 August 2019

Accepted: 27 October 2019

\begin{abstract}
In this study, seasonal stable isotope compositions of zooplankton and particulate organic matter were analyzed from the coastal zone in Kepez Harbor, the discharge point of a waste treatment plant. The results were compared with the results of a control station located $10 \mathrm{~km}$ away from the harbor. Zooplankton samples were collected horizontally with a $200 \mu \mathrm{m}$ mesh plankton net from the surface waters. POM samples were collected with a 5L Nansen bottle and filtered through precombusted GF/F filters. Variables such as temperature, salinity, chlorophyll- $a$ as well as oil-grease and chemical oxygen demand were also determined in the study sites. The salinity values in the control station were significantly higher than the harbor station through the whole year. The $\delta^{13} \mathrm{C}$ values of POM in the control station were significantly higher than the values observed in the harbor station. The $\delta^{15} \mathrm{~N}$ values of zooplankton in the harbor were higher than the values obtained in the control station; however, the differences were not significant. The values of oil-grease obtained in two stations were lower than the values pronounced in EPA, EU, and Turkish Regulations. The study showed that the stable isotope compositions were affected by terrestrial inputs and high currents rather than the facilities comprised in the harbor.
\end{abstract}

Keywords: $\delta^{13} \mathrm{C}, \delta^{15} \mathrm{~N}$, water pollution, food web, seasonal variation

\section{Introduction}

Factors such as increasing population, urbanization and industrialization in the last century threaten marine ecosystems, especially coastal areas. Many studies have been carried out using different methods to determine

*e-mail: sinanuzundumlu@gmail.com the effects of industrial and anthropogenic waste on marine ecosystems [1-6]. As waste oil is treated in the harbors that contain various waste separation activities such as Kepez Harbor in the Dardanelles, it is expected that there will be oil-grease input in the system if it is not treated properly. Such a situation may cause pollution in the receiving environment, disrupting the structure of both the benthic and the pelagic ecosystems. In developed countries, various government agencies 
or non-governmental organizations determine the limit values that can be discharged into the receiving environment with various directives and regulations. Within the scope of the coastal ecosystem, keeping such situations under control is left to the responsibility of industrial facilities. In Turkey, the facilities that discharge to marine systems or inland waters also control the effects of the treatment plants to the aquatic systems by making routine analyses of the variables such as heavy metals, oil-grease, biological oxygen demand (BOD) and chemical oxygen demand (COD) in their facility laboratories or other accredited ones. However, there may be some amount of inorganic waste input into the receiving system even though it may be below the limit values provided by the international or the national organizations. Thus, stable isotope analysis can be an effective method to determine the possible effects of such conditions on marine systems.

Stable isotopes have been used extensively in order to determine the effects of waste and terrestrial inputs discharged into aquatic environments, sources of pollution and food web interactions [7, 8]. However, the number of studies in the coastal areas and in the regions where industrial activities may affect the quality of the coastal ecosystem is very low [9]. Mesozooplankton play an important role in transferring organic matter from phytoplankton and other organic materials (POM) to the higher trophic levels due to their trophic position. For this reason, they also have a role in the transport of pollution to the upper layers in the marine system. In marine ecosystems, $\delta^{13} \mathrm{C}$ and $\delta^{15} \mathrm{~N}$ isotopes are frequently used to determine the sources of organic matter and their transfer through the trophic level [10, 11]. Consequently, consumer's tissue $\delta^{15} \mathrm{~N}$ can be used to estimate the trophic levels of organisms because they typically show $2.5-4.5 \%$ enrichment relative to their prey [12]. Conversely, the $\delta^{13} \mathrm{C}$ ratio in the tissue of the organism is enriched very weakly through higher trophic levels with $0.4-2.0 \%$, which can act as a useful indicator of the primary organic carbon source of an organism's food intake [13]. Therefore, when $\delta^{13} \mathrm{C}$ is used to determine the nutritional carbon source of organisms, $\delta^{15} \mathrm{~N}$ is used to estimate the trophic level that they may belong to.

The present study was conducted in Kepez Harbor (Port of Çanakkale) in the Dardanelles, where Çanakkale Strait plays a crucial role in transporting nutrients, plankton and fish communities between the Black Sea and the Mediterranean [14]. It is known that there are daily changes in nutrients as a result of discharges and terrestrial inputs in the Dardanelles [15-17]. In addition, the strait has a special two-layer flow regime in which the upper layer of the water column is composed of waters with low salinity level from the Black Sea, while the lower layer consists of waters with high salinity originating from the Mediterranean [18]. The aim of this study was to investigate the effects of the water discharged from the waste reception facility in Kepez Harbor to the marine system of the area. The objectives were: (i) to determine and compare the zooplankton and POM stable isotope compositions of the station in the harbor and the control station, (ii) to determine the differences of physicochemical and biological factors between these stations (iii) and to determine the possible causes of these differences.

\section{Material and Methods}

The study was carried out in two stations in the Dardanelles between Autumn 2016 and Summer 2017. The first station is the coastal region where the waste water treatment plant belonging to the waste reception facility operating in Kepez Harbor has a discharge (Fig. 1). This station may occasionally be under the influence of strong currents, it is closer to the settlement and can be affected from terrestrial inputs. The depth of the station varies from 3 to $3.5 \mathrm{~m}$. The $2^{\text {nd }}$ station is the control station and is a coastal area about $10 \mathrm{~km}$ southwest of the first station (Fig. 1). It has no terrestrial inputs and is less affected by the currents compared to the first station, and its depth varies between 2-2.5 m.

Temperature and salinity values were determined in situ using a YSI 650 MPS. Water samples for chlorophyll-a (Chl-a) measurement were collected from the surface with a 5L Nansen bottle and filtered through a $47 \mathrm{~mm}$ diameter GF/F. Spectrophotometric determination was conducted according to [19] after $90 \%$ acetone extraction. Total suspended solids (TSS) determination was performed gravimetrically after the water samples were filtered through $\mathrm{GF} / \mathrm{C}$ filters [20]. Chemical oxygen demand (COD) and oil-grease analysis were conducted using the open reflux method and standard methods for the examination of water and wastewater according to [21].

Samples for the stable isotope analyses (SIA) of POM were collected from the two stations with a $5 \mathrm{~L}$ Nansen bottle. The samples were first filtered through a $50 \mu \mathrm{m}$ plankton net to remove large organisms, then filtered again through precombusted $\left(400^{\circ} \mathrm{C}, 3\right.$ hours) $\mathrm{GF} / \mathrm{F}$ filters and dried in a drying oven at $60^{\circ} \mathrm{C}$ for 24 hours. Zooplankton samples for SIA were collected horizontally with a $200 \mu \mathrm{m}$ pore-sized plankton net from surface waters of the two stations. $200 \mu \mathrm{m}$ - to $1000 \mu \mathrm{m}$ sized zooplankton were targeted, and larger organisms were removed from the samples under the microscope. Then bulk zooplankton samples were kept in $-80^{\circ} \mathrm{C}$ until SIA. Before analysis the bulk samples were dried in a drying oven at $60^{\circ} \mathrm{C}$ for 24 hours and each sample was weighed $(0.150 \mathrm{mg})$ in tin capsules. The SIA for zooplankton and POM samples were conducted using an isotope ratio mass spectrometer (Delta V Thermo Finnigan; Thermo, Waltham, USA) in the Akdeniz University Food Safety and Agricultural Research Center. Since acidification can affect the nitrogen and carbon isotope values, the samples were not acidified 

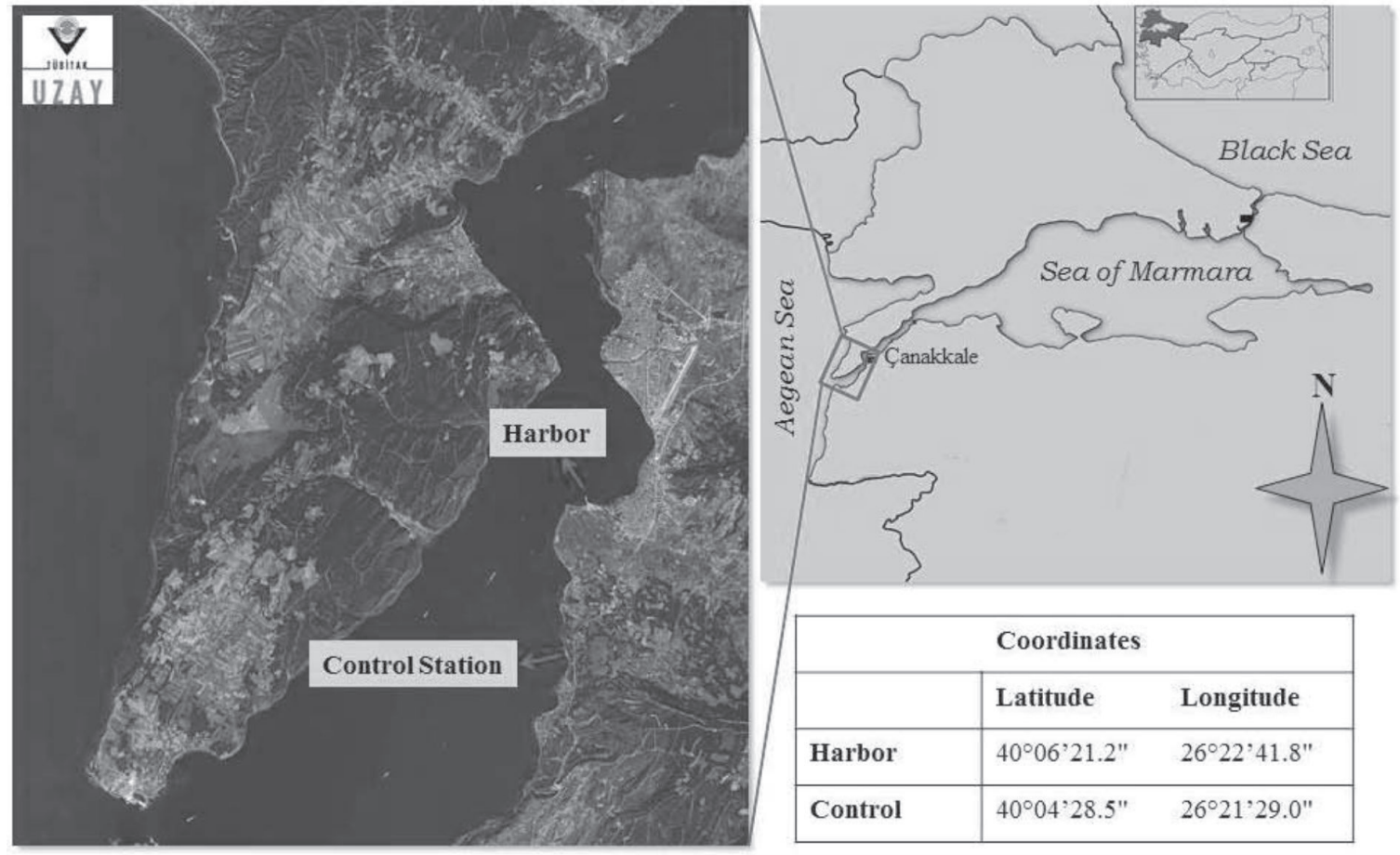

Fig. 1. Location of the sampling sites in the Dardanelles.

[22]. The obtained results are expressed by $\delta$ using the following equation:

$$
\delta^{13} \mathrm{C} \text { or } \delta^{15} \mathrm{~N}(\%)=(\text { Rsample/Rstandard-1) } \mathrm{x} 1000
$$

...where the stable isotope abundance of $\mathrm{C}$ and $\mathrm{N}$ was expressed as $\delta^{13} \mathrm{C}$ or $\delta^{15} \mathrm{~N},{ }^{13} \mathrm{C} /{ }^{12} \mathrm{C}$ or ${ }^{15} \mathrm{~N} /{ }^{14} \mathrm{~N}$. The stable isotope ratio was represented by $\mathrm{R}$ with the reference being V-PDB (Vienna Pee Dee Belemnite) and atmospheric $\mathrm{N}_{2}$ isotope standards.

To determine the spatial differences between physico-chemical variables and the stable isotope ratios of zooplankton and POM, one-way analyses of variances (ANOVAs; significance level $p<0.05$ ) were used. The different groups were analyzed using Tukey's honestly significant difference (HSD) test for unequal
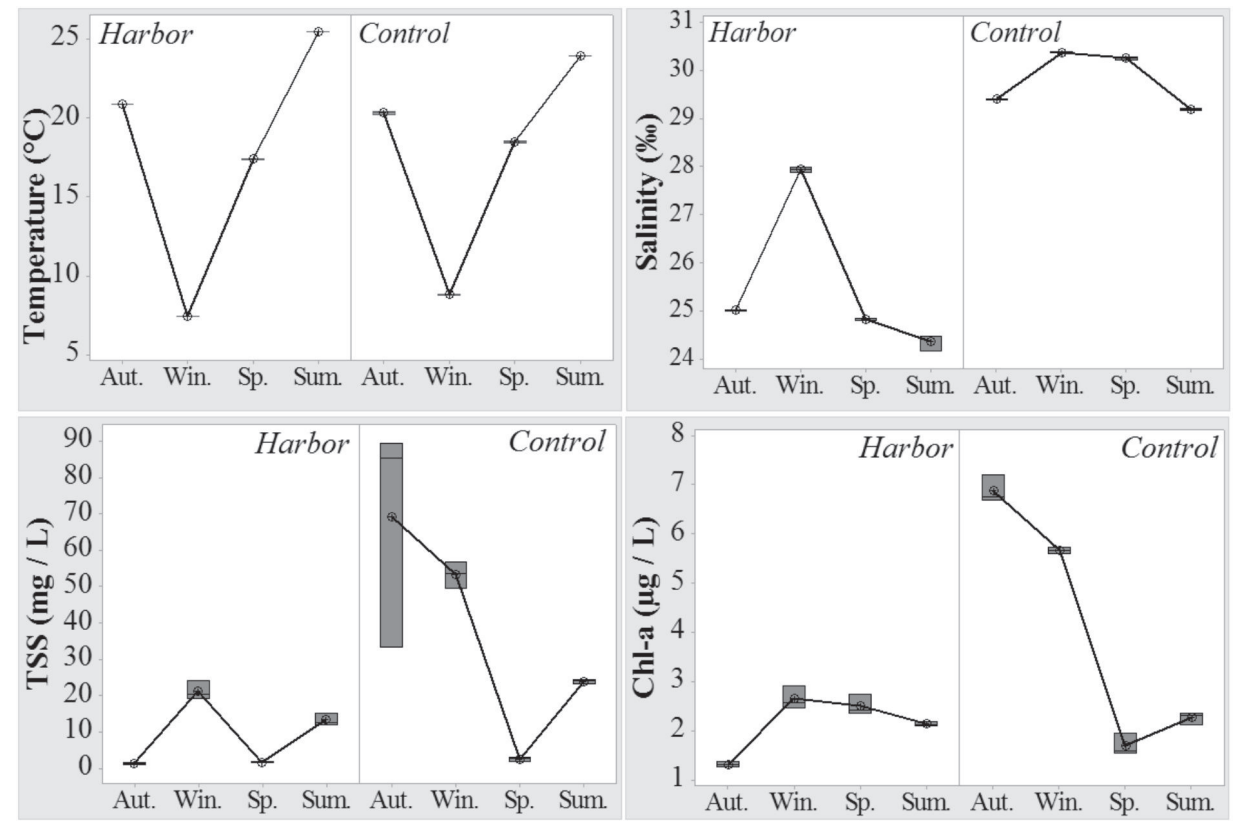

Fig. 2. Temporal boxplots of physco-chemical variables in study area (Aut.: autumn, Win.: winter, Sp.: spring, Sum.: summer; all water quality parameters were determined in triplicate). 
Table 1. Results of one-way ANOVA and Tukey's HSD post hoc tests on spatial variations of stable isotope compositions of zooplankton and POM in each season.

\begin{tabular}{|c|c|c|c|c|c|c|}
\hline Variable & Factor & $\mathrm{n}$ & $*$ mean \pm SD & $\begin{array}{l}\text { Significance } \\
\text { ( } p \text { value) }\end{array}$ & $\min$. & $\max$. \\
\hline \multirow{2}{*}{$\begin{array}{c}\text { Temperature } \\
\left({ }^{\circ} \mathrm{C}\right)\end{array}$} & Harbor & 12 & $17,78 \pm 6,93^{\mathrm{a}}$ & \multirow{2}{*}{ n.s. } & 7.41 & 25.45 \\
\hline & Control & 12 & $17,89 \pm 5,85^{\mathrm{a}}$ & & 8.79 & 23.96 \\
\hline \multirow{2}{*}{$\begin{array}{l}\text { Salinity } \\
(\%)\end{array}$} & Harbor & 12 & $25,543 \pm 1,466^{\mathrm{b}}$ & \multirow{2}{*}{$<0.001$} & 24.18 & 27.98 \\
\hline & Control & 12 & $29,798 \pm 0.539^{\mathrm{a}}$ & & 29.17 & 30.38 \\
\hline \multirow{2}{*}{$\begin{array}{c}\text { Chl- } a \\
\left(\mu \mathrm{g} \mathrm{L}^{-1}\right)\end{array}$} & Harbor & 12 & $2,149 \pm 0,559^{\mathrm{b}}$ & \multirow{2}{*}{$<0.05$} & 1.26 & 2.90 \\
\hline & Control & 12 & $4,125 \pm 2,309^{a}$ & & 1.53 & 7.21 \\
\hline \multirow{2}{*}{$\begin{array}{c}\mathrm{TSS} \\
\left(\mathrm{mg} \mathrm{L}^{-1}\right)\end{array}$} & Harbor & 12 & $9,38 \pm 8,87^{b}$ & \multirow{2}{*}{$<0.05$} & 1.10 & 24.20 \\
\hline & Control & 12 & $37,27 \pm 30,12^{\mathrm{a}}$ & & 2.00 & 89.33 \\
\hline \multirow{2}{*}{$\begin{array}{c}\mathrm{COD} \\
\left(\mathrm{mg} \mathrm{L}^{-1}\right)\end{array}$} & Harbor & 4 & $51.7 \pm 38.70^{\mathrm{a}}$ & \multirow{2}{*}{ n.s. } & 19.80 & 108.00 \\
\hline & Control & 4 & $57.9 \pm 42.2^{\mathrm{a}}$ & & 19.84 & 117.60 \\
\hline \multirow{2}{*}{$\begin{array}{c}* * \text { Oil - Grease } \\
\left(\mathrm{mg} \mathrm{L}^{-1}\right)\end{array}$} & Harbor & 4 & $<0.01$ & \multirow{2}{*}{-} & n.a. & n.a. \\
\hline & Control & 4 & $<0.01$ & & n.a. & n.a. \\
\hline \multirow{2}{*}{$\begin{array}{c}\delta^{13} \mathrm{C}_{\mathrm{Zoo}} \\
(\% \mathrm{o})\end{array}$} & Harbor & 12 & $-22.095 \pm 0.761^{\mathrm{a}}$ & \multirow{2}{*}{ n.s. } & -23.33 & -21.01 \\
\hline & Control & 9 & $-21.982 \pm 0.937^{\mathrm{a}}$ & & -23.19 & -20.76 \\
\hline \multirow{2}{*}{$\begin{array}{l}\delta^{13} \mathrm{C}_{\text {Pom }} \\
(\% 0)\end{array}$} & Harbor & 12 & $-21.536 \pm 1.947^{b}$ & \multirow{2}{*}{$<0.05$} & -23.81 & -17.77 \\
\hline & Control & 6 & $-19.444 \pm 1.332^{\mathrm{a}}$ & & -21.03 & -17.27 \\
\hline \multirow{2}{*}{$\begin{array}{l}\delta^{15} \mathrm{~N}_{\text {Zoo }} \\
(\%)\end{array}$} & Harbor & 12 & $5.251 \pm 0.796^{\mathrm{a}}$ & \multirow{2}{*}{ n.s. } & 3.93 & 6.19 \\
\hline & Control & 6 & $4.321 \pm 1.574^{\mathrm{a}}$ & & 2.62 & 6.05 \\
\hline \multirow{2}{*}{$\begin{array}{l}\delta^{15} \mathrm{~N}_{\text {Pom }} \\
(\% 0)\end{array}$} & Harbor & 12 & $3.075 \pm 1.160^{\mathrm{a}}$ & \multirow{2}{*}{ n.s. } & 0.92 & 4.40 \\
\hline & Control & 6 & $3.960 \pm 1.091^{\mathrm{a}}$ & & 2.51 & 5.40 \\
\hline
\end{tabular}

*different letters indicate significantly different means (one-way ANOVA, Tukey's post hoc tests at $\mathrm{P}<0.05$ ) among the species ("a" indicates the highest value).

**All values of oil and grease in each station were lower than $0.01 \mathrm{mg} \mathrm{L}^{-1}$.

n.s.: Not significant

n.a.: Not available.

sample sizes for post hoc comparisons among stations. Pearson's correlation analyses were applied to find out whether there is a linear relationship between variables observed in the study area. For the analyses we used SPSS 18.0 and Minitab 17.1.0.

\section{Results and Discussion}

Results of the one-way ANOVA (significance level $p<0.05)$ determined during the study are shown in Table 1. The water temperature values in the study area followed a seasonal cycle, the lowest value being $7.41^{\circ} \mathrm{C}$ in winter and the highest value being $25.45^{\circ} \mathrm{C}$ in summer in the harbor station (Fig. 2). There was no significant difference in temperature between stations (Table $1 ; p>0.05$ ). Salinity values of the control station were significantly higher than the harbor station (Fig. 2, Table $1 ; p<0.001)$. The highest salinity value was $30.38 \%$ and it was determined in the control station in winter, while the lowest value was $24.18 \%$ in the harbor station in summer. Chl- $a$ values were in the range of 1.26-2.90 $\mathrm{g} \mathrm{L} \mathrm{L}^{-1}$ in the harbor and 1.53-7.21 $\mu \mathrm{g} \mathrm{L}^{-1}$ in the control station. Chl- $a$ values were statistically significant among stations (Fig. 2, Table 1; $p<0.05$ ). In terms of TSS, high values were observed in the control station compared to the harbor and the differences between the stations were statistically significant (Table $1 ; p<0.05$ ). While chl- $a$ values showed significant positive correlation with TSS in the control station, there wasn't a significant relation in the harbor (Table 2). The differences between stations were not found to be significant in COD values, while both the highest (in spring) and the lowest (in winter) 
Table 2. Pearson linear correlations between physico-chemical variables and stable isotope values of zooplankton and POM at the study site.

\begin{tabular}{|c|c|c|c|c|}
\hline \multirow{2}{*}{ Variables } & \multicolumn{2}{|c|}{ Harbor } & \multicolumn{2}{|c|}{ Control } \\
\hline & $r$ & $p$ & $r$ & $p$ \\
\hline chl- $a$ vs TSS & 0.542 & n.s. & 0.851 & $<0.001$ \\
\hline chl- $a$ vs $\delta^{13} \mathrm{C}_{\mathrm{zoo}}$ & 0.540 & n.s. & 0.134 & n.s. \\
\hline chl- $a$ vs $\delta^{13} \mathrm{C}_{\mathrm{POM}}$ & -0.529 & n.s. & 0.642 & n.s. \\
\hline$\delta^{13} \mathrm{C}_{\mathrm{zoo}}$ vs $\delta^{13} \mathrm{C}_{\mathrm{POM}}$ & -0.305 & n.s. & 0.134 & n.s. \\
\hline TSS vs $\delta^{15} \mathrm{~N}_{\mathrm{zoo}}$ & 0.782 & $<0.05$ & 0.547 & n.s. \\
\hline TSS vs $\delta^{15} \mathrm{~N}_{\text {POM }}$ & 0.666 & $<0.05$ & -0.472 & n.s. \\
\hline
\end{tabular}

n.s.: Not significant

values were determined in the control station (Table $1 ; p>0.05)$. Oil and grease amounts were lower than $0.1 \mathrm{mg} \mathrm{L}^{-1}$ at all stations throughout the sampling period (Table 1).

Although COD vales did not exceed the limit values as defined by the WCPR all through the sampling period, it was observed that the limit values of COD as defined by EU and EPA were exceeded during the spring and the summer samplings in the harbor station, and the autumn and the spring samplings in the control station (Table 3). The oil-grease values did not exceed the limit values defined in the EPA, EU and WCPR throughout the year (Table 3). Recently, no research has been conducted on COD in the marine system of the region, and the previous studies carried out were mostly in inland waters. For example, in a study conducted in 2001 [23], the COD values in Sarıçay River, which flows through the Strait, were found to be between 62 and $88 \mathrm{mg} \mathrm{L}^{-1}$, showing that this river plays an important role in transporting pollutants to the coastal system.

Table 3. Limit values for water quality variables in national and international organizations.

\begin{tabular}{|c|c|c|c|}
\hline Variable & $\mathrm{WPCR}^{1}$ & $\mathrm{EU}^{2}$ & $\mathrm{EPA}^{3}$ \\
\hline Temperature $\left({ }^{\circ} \mathrm{C}\right)$ & 30 & 25 & 25 \\
\hline Salinity $(\%)$ & n.a. & n.a. & $<40$ \\
\hline $\mathrm{TSS}\left(\mathrm{mg} \mathrm{L}^{-1}\right)$ & 100 & n.a. & 50 \\
\hline $\mathrm{pH}$ & $6.0-9.0$ & $6.5-9.0$ & $5.5-9.0$ \\
\hline $\mathrm{COD}\left(\mathrm{mg} \mathrm{L}^{-1}\right)$ & 200 & 30 & 40 \\
\hline Oil-Grease $\left(\mathrm{mg} \mathrm{L}^{-1}\right)$ & $10-20$ & $0.05-1$ & $0.01-1$ \\
\hline
\end{tabular}

n.a.: Not available.

${ }^{1}$ Water Pollution Control Regulation of Republic of Turkey (Limit values for Solid Waste Assessment and Disposal Facilities).

${ }^{2}$ European Union (Surface Water Quality Standards). ${ }^{3}$ Environmental Protection Agency (Parameters of Water Quality - Interpretation and Standards; Recommended or Mandatory Limit Values).
In another study conducted in the Mediterranean coastal system, it was found that anthropogenic and industrial wastes increased COD values in the marine system [24]. The results obtained in both studies showed similarity with the present study. On the other hand, COD values obtained in a study conducted in a wastewater treatment plant in the Marmara Region were found to be significantly higher than the COD values obtained in our study [25], while in another study conducted in the mouth of a river in the Black Sea the values were found to be very low [26].

Stable carbon isotope values of zooplankton (hereafter $\delta^{13} \mathrm{C}_{\mathrm{zoo}}$ ) at the harbor station showed lower values in autumn and winter than in spring and summer, when surface water temperatures were high. Spatial variations of $\delta^{13} \mathrm{C}_{\text {zoo }}$ were not statistically significant (Table $1 ; p>0.05$ ). The stable carbon isotope values of POM (hereafter $\delta^{13} \mathrm{C}_{\mathrm{POM}}$ ) determined at the control station were significantly higher than the harbor station (Table $1 ; p<0.05$ ). Even the stable isotope nitrogen values of zooplankton $\delta^{15} \mathrm{~N}$ (hereafter $\delta^{15} \mathrm{~N}_{\text {zoo }}$ ) showed higher variations in the harbor station than in the control, the differences between stations were not significant (Table $1 ; p>0.05$ ). The variations of the stable nitrogen isotope values of POM (hereafter $\delta^{15} \mathrm{~N}_{\mathrm{POM}}$ ) between stations were not significant (Table $1 ; p>0.05$ ). TSS values showed significant positive correlation with $\delta^{15} \mathrm{~N}_{\text {zoo }}$ and $\delta^{15} \mathrm{~N}_{\text {POM }}$ in the harbor station (Table 2).

The $\delta^{13} \mathrm{C}_{\mathrm{POM}}$ values measured in the harbor station were significantly lower than the control station (Table $1 ; p<0.05$ ), suggesting that the sampling areas were under the influence of different carbon sources. Possible causes of these variations may include anthropogenic terrestrial inputs, different current effects in the coastal area (Mediterranean and Black Sea originated), changing phytoplanktonic load along the Strait and/or harbor-originated wastes [27, 28]. Previously conducted studies have shown that oilgrease input to marine systems (oil-based) may cause depletion in $\delta^{13} \mathrm{C}_{\mathrm{POM}}$ and $\delta^{13} \mathrm{C}_{\mathrm{zoo}}$ values [29-31]. In the present study, $\delta^{13} \mathrm{C}_{\mathrm{POM}}$ (significant; $p<0.05$ ) and $\delta^{13} \mathrm{C}_{\mathrm{zoo}}$ (not significant; $p>0.05$ ) values determined in the harbor 
station were lower than the control station (Table 1), suggesting a possible oil input to the system although the oil-grease values were below the limit values (Table 3). Furthermore, COD hasn't been associated with the isotopic ratios of primary consumers or POM in recently conducted studies where there is a possible oil input to the system. Indeed, no correlations were found between COD and stable isotope values of both zooplankton and POM in the current study.

The variation in chl- $a$ and TSS values determined in the region showed that the load in the system may vary for many reasons. For example, the significant linear relationship between TSS and chl- $a$ in the control station can be an indication that TSS in this station may have originated from phytoplankton [32]. In contrast, there was no significant linear relationship between TSS and chl- $a$ at the harbor station, meaning that TSS in the port was not of phytoplanktonic origin but had a different source (Table 2). Furthermore, the salinity values at the control station were significantly higher than the harbor station all through the sampling period (Table $1 ; p<0.05$ ), indicating that this station can be exposed to the currents flowing from the Mediterranean rather than the ones from the Black Sea. In other words, since the food sources in the control station were of Mediterranean origin, stable isotope ratios may differ from the harbor station. A similar situation has also been determined by [32] and it has been stated that current systems may have an important role in the exchange of food resources.

It is known that terrestrial sources such as detritus and anthropogenic inputs can affect primary consumers and POM's stable isotope compositions [27, 33]. Thus, Fig. 3 shows that POM in the control station (PC) seems to be under the influence of higher carbon sources. Therefore, it can be stated that in this study POM was under the influence of very high carbon- derived phytoplanktonic organisms rather than lowcarbon terrestrial inputs (detritus, anthropogenic inputs) in the control station. The chl- $a$ values, indicative of the phytoplanktonic load, were significantly higher in the control station when compared to the harbor station (Table $1 ; p<0.05$ ) supporting this idea. In addition, the stable $\mathrm{C}$ and $\mathrm{N}$ ratios of the POM obtained at the control station were similar to the previously conducted studies offshore - far from terrestrial inputs $[34,35]$. Therefore, this may support the idea that the control station is not under the influence of terrestrial inputs.

Although there was no significant difference between the stations in terms of $\delta^{15} \mathrm{~N}_{\text {Zoo }}$ values, the $\delta^{15} \mathrm{~N}_{\text {Zoo }}$ values measured in the harbor were higher than the control station. It is known that $\delta^{15} \mathrm{~N}_{\text {zoo }}$ is generally enriched in coastal regions where anthropogenic terrestrial inputs are high [36,37]. One reason for the enrichment of $\delta^{15} \mathrm{~N}_{\mathrm{Zoo}}$ in this region can be the fact that the harbor is closer to the terrestrial sources such as anthropogenic inputs. Similar to the present research, in a study conducted by [38], it has been observed that the $\delta^{15} \mathrm{~N}_{\text {zoo }}$ values were enriched in coastal regions compared to the open seas. Therefore, it can be stated that stable isotope compositions belonging to the zooplankton and POM in the harbor station can be under the influence of terrestrial inputs rather than harbor wastes. Thus, the significant positive correlation between TSS and $\delta^{15} \mathrm{~N}_{\text {Zoo }}$ as well as $\delta^{15} \mathrm{~N}_{\mathrm{POM}}$ in the harbor station may support this idea (Table 2).

With this study, it was clearly understood that the load in the harbor station originated from the terrestrial inputs, while the load in the control station originated from phytoplankton, which could affect the isotopic values of zooplankton and POM. In addition, the isotopic values of zooplankton and POM measured during the study were similar to the previous studies

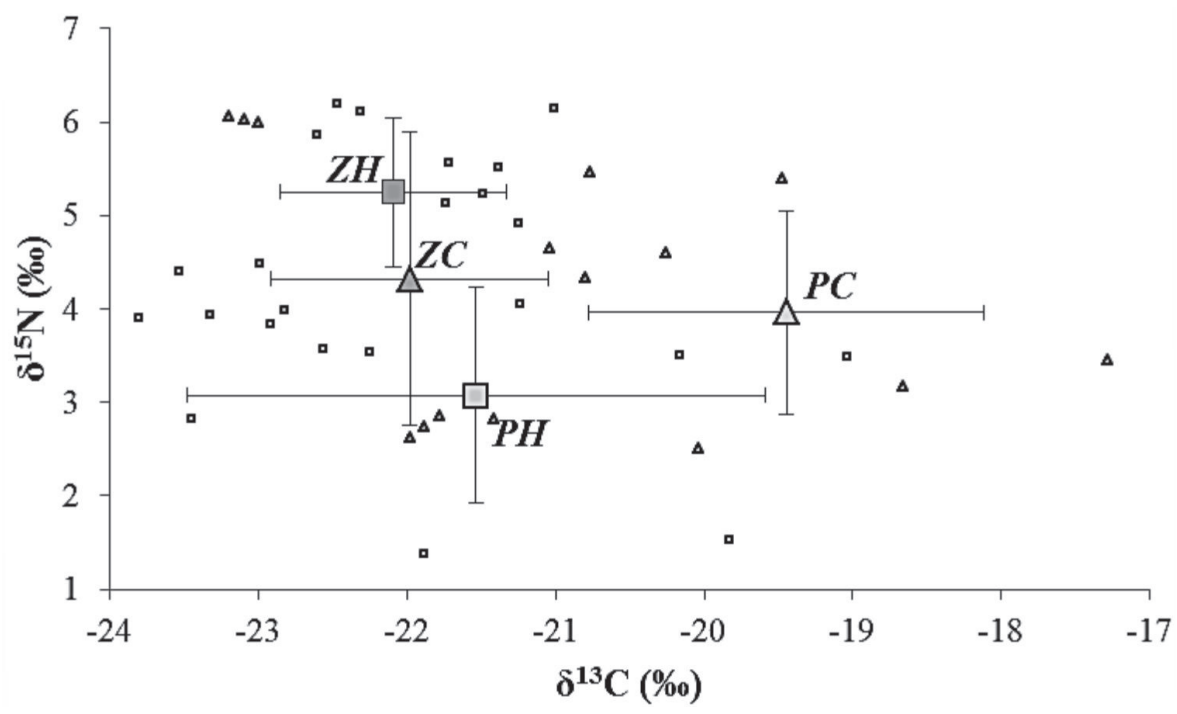

Fig. 3. Spatial scatter plots (mean $\pm \mathrm{SD}$ ) of stable isotope compositions of zooplankton and POM in the Dardanelles (ZH: zooplankton in harbor, ZC: zooplankton in control station, PC: POM in control station, PH: POM in harbor station). 
conducted close to the region and no high differences were observed $[11,39,40]$. Nevertheless, the values of physico-chemical and biological variables were similar to those recorded in the previous studies in the region $[2,4,5,41]$.

\section{Conclusions}

Considering the data evaluation in the study area, it can be specified that the wastewater plant discharge in the harbor had a trivial effect on the ecosystem of the coastal area and that the changes in $\delta^{13} \mathrm{C}$ and $\delta^{15} \mathrm{~N}$ values of the primary consumers and POMs in the region were mostly due to terrestrial inputs, different phytoplanktonic loads and the special current system in the Strait. Additionally, it can be stated that the control station contains food sources of Mediterranean origin while the harbor region contains food sources of Black Sea origin. Thus, being the first stable isotope study on zooplankton and POM in the region, this study is expected to be a reference for future food web studies in the region. However, in order to understand the dynamics better, it is recommended to carry out more comprehensive studies including the effects of estuarine inputs to the strait and other point sources such as sewage inputs.

\section{Acknowledgements}

This research was funded by the Çanakkale Onsekiz Mart University Research Foundation (BAP, Project \#FDK 2016/869 and \#FHD-2018-1432). Thanks are extended to Şükran Yalçın Özdilek for the constructive criticism on an earlier draft of the manuscript, and to Canakkale Liman Isletmesi Sanayi ve Ticaret A.S. for logistical support.

\section{Conflict of Interest}

The authors declare no conflict of interest.

\section{References}

1. YILMAZ S., SADIKOĞLU M. Study of heavy metal pollution in seawater of Kepez harbor of Canakkale (Turkey). Environ Monit Assess. 173, 899, 2011.

2. ATEŞ A.S., KATAĞAN T., SEZGIN M., BERBER S., ÖZDILEK H. G., KOLSAL S. Recent data on the effects of sewage pollution on the assemblage of decapod crustaceans in the Dardanelles (the Turkish Straits System). J. Black Sea/Mediterranean Environment. 17 (2), 90, 2011.

3. ATEŞ A.S., KATAĞAN T., SEZGIN M., ÖZDILEK H.G, BERBER S., BULUT M. The effects of some domestic pollutants on the cumacean (Crustacea) community structure at the coastal waters of the Dardanelles, Turkey. Arthropods. 3 (1), 27, 2014.
4. ÇULHA S.T., DERELI H., KARADUMAN F.R., ÇULHA M. Assessment of trace metal contamination in the sea cucumber (Holothuria tubulosa) and sediments from the Dardanelles Strait (Turkey). Environ. Sci. Pollut. Res. 23, 11584, 2016.

5. TÜRKMEN C., AYYILDIZ O., AKBULUT M., KAYA H. Microbial Quality in Coastal Waters of Dardanelles in Relation to the Pollution Sources and Transport Pathways. Clean - Soil, Air, Water. 40 (12), 1320, 2012.

6. OZYIGIT I.I., UYANIK O.L., SAHIN N.R., YALCIN I.E., DEMIR G. Monitoring the Pollution Level in Istanbul Coast of the Sea of Marmara Using Algal Species Ulva lactuca L. Pol. J. Environ. Stud. 26 (2), 773, 2017.

7. DE LECEA A.M., FENNESSY S.T., SMIT A.J. Processes controlling the benthic food web of a mesotrophic bight (KwaZulu-Natal, South Africa) revealed by stable isotope analysis. Mar Ecol Prog Ser. 484, 97, 2013.

8. WILK-WOZNIAK E., POCIECHA A., AMIROWICZ, GĄSIOROWSKI M., GADZINOWSKA J. Do planktonic rotifers rely on terrestrial organic matter as a food source in reservoir ecosystems? Int. Rev. Hydrobiol. 99, 157, 2014.

9. RUMOLO P., BARRA M., GHERARDI S., MARSELLA E., SPROIVERI M. Stable isotopes and $\mathrm{C} / \mathrm{N}$ ratios in marine sediments as a tool for discriminating anthropogenic impact. J. Environ. Monit. 13, 3399, 2011.

10. DE LECEA A.M., COOPER R., SMIT A.J. Identifying the drivers of the pelagic ecosystem of an oligotrophic bight (KwaZulu - Natal , South Africa) using stable isotopes $\left(\delta^{13} \mathrm{C}, \delta^{15} \mathrm{~N}\right)$ and $\mathrm{C}: \mathrm{N}$ ratio analysis. Marine and Freshwater Research. 67, 1750, 2016.

11. BĂNARU D., CARLOTTI F., BARANI A., GRÉGORI G., NEFFATI N., HARMELIN-VIVIEN M. Seasonal variation of stable isotope ratios of size-fractionated zooplankton in the Bay of Marseille (NW Mediterranean Sea). J. Plankton Res. 36, 145, 2014.

12. OWENS N.J.P. Natural variations in ${ }^{15} \mathrm{~N}$ in the marine environment. Adv. Mar. Biol. 24, 389, 1987.

13. POST D.M. Using stable isotopes to estimate trophic position: models, methods, and assumptions. Ecology. 83 (3), 703, 2002.

14. OZTURK B., OZTURK A.A. On the biology of the Turkish straits system. Bull. Inst. Océanogr. 17, 205, 1996.

15. ODABAŞI S., BUYUKATES Y. Klorofil-a, Çevresel parametreler ve besin elementlerinin günlük değişimleri: Sariçay akarsuyu örneği (Çanakkale, Türkiye). Ekoloji. 19 (73), 76, 2009 [In Turkish].

16. YALÇIN B., ARTÜZ M.L., PAVLIDOU A., ÇUBUK S., DASSENAKIS M. Nutrient dynamics and eutrophication in the Sea of Marmara: Data from recent oceanographic research. Sci Total Environ. 602, 405, 2017.

17. SOUVERMEZOGLOU E., KRASAKOPOULOU E., PAVLIDOU A. Temporal and spatial variability of nutrients and oxygen in the North Aegean Sea during the last thirty years. Mediterranean Marine Science. 15, 805, 2014.

18. JAROSZ E., TEAGUE W.J., BOOK J.W., BESIKTEPE Ş.T. Observations on the characteristics of the exchange flow in the Dardanelles Strait. J Geophys Res. 117, 1, 2012.

19. 19. American Water Works Association (USA); Water Environment Federation (USA). Standard methods for the examination of water and wastewater. Washington DC, 1995.

20. CLESCERI L.S., GREENBERG A.E., EATON A.D. Standard Methods for the Examination of Water and Wastewater. 20th ed. Washington, DC. American Public Health Association, 1220, 1998. 
21. EATON A.D., FRANSON M.A. Water Environment Federation. Standard Methods for the Examination of Water\&Wastewater. Washington, DC. American Public Health Association, 2005.

22. BUNN S., LONERAGAN N.R., KEMPSTER M.A. Effects of Acid Washing on Stable Isotope Ratios of C And $\mathrm{N}$ in Penaeid Shrimp and Seagrass: Implications For Food-Web Studies Using Multiple Stable Isotopes,.Limnol. Oceanogr. 40, 622, 1995.

23. Anonymus. Environmental Condition Report. Çanakkale, 2001 [In Turkish].

24. DRIRA Z., KMIHA-MEGDICHE S., SAHNOUN H., HAMMAMI A., ALLOUCHE N., TEDETTI M., AYADI $\mathrm{H}$. Assessment of anthropogenic inputs in the surface waters of the southern coastal area of Sfax during spring (Tunisia, Southern Mediterranean Sea). Mar. Pollut. Bull. 104, 355, 2016.

25. AY M., KISI O. Modelling of chemical oxygen demand by using ANNs, ANFIS and k-means clustering techniques. J Hydrol. 511, 279, 2014.

26. BAYRAM A., ÖNSOY H., Harşit çayı (Giresun - Tirebolu) tarafından Karadeniz'e taşınan kirleticilerin belirlenmesi. 7. Kıyı Mühendisliği Sempozyumu. 545, 2011 [In Turkish].

27. BERTO D., RAMPAZZO F., NOVENTA S., CACCIATORE F., GABELLINI M., BERNARDI AUBRY F., GIROLIMETTO A., BOSCOLO BRUSÀ R. Stable carbon and nitrogen isotope ratios as tools to evaluate the nature of particulate organic matter in the Venice lagoon. Estuar Coast Shelf Sci. 135, 66, 2013.

28. ESPINASSE B., TIANO M., GUILLOUX L. Patterns of variations in $\mathrm{C}$ and $\mathrm{N}$ stable isotope ratios in sizefractionated zooplankton in the Gulf of Lion, NW Mediterranean Sea. J. Plankton Res. 36 (5), 1204, 2018.

29. SPIES R., DESMARAIS D. Natural isotopes study of trophic enrichment of marine benthic communities by petrolium seepage. Mar Biol. 73, 67, 1983.

30. GRAHAM W.M., CONDON R.H., CARMICHAEL R.H., D'AMBRA I., PATTERSON H.K., LINN L.J., HERNANDEZ JR F.J. Oil carbon entered the coastal planktonic food web during the deepwater horizon oil spill. Environ. Res. Lett. 5, 2010.

31. CHANTON J.P., CHERRIER J., WILSON R.M., SARKODEE-ADOO J., BOSMAN S., MICKLE A., GRAHAM W.M. Radiocarbon evidence that carbon from the deepwater horizon spill entered the planktonic food web of the gulf of Mexico. Environ. Res. Lett. 7, 2012.

32. BUYUKATES Y., CELIKKOL B., YIGIT M., DECEW J., BULUT M. Environmental monitoring around an offshore fish farm with copper alloy mesh pens in the Northern Aegean Sea. Am. J. Environ. Prot. 6 (2), 50, 2017.

33. BRISTOW L.A., JICKELLS T.D., WESTON K., MARCABELL A., PARKER R., ANDREWS J.E. Tracing estuarine organic matter sources into the southern North Sea using C and $\mathrm{N}$ isotopic signatures. Biogeochemistry. 113, 9, 2013.

34. SOARES M.A., BHASKAR P.V., NAIK R.K., DESSAI D., GEORGE J., TIWARI M., ANILKUMAR N. Latitudinal $\delta^{13} \mathrm{C}$ and $\delta^{15} \mathrm{~N}$ variations in particulate organic matter (POM) in surface waters from the Indian ocean sector of Southern Ocean and the Tropical Indian Ocean in 2012. Deep-Sea Res Pt II. 118, 186, 2015.

35. HENSCHKE N., EVERETT J.D.,. SUTHERS I.M., SMITH J.A., HUNT B.P.V., DOBLIN M.A., TAYLOR M.D. Zooplankton trophic niches respond to different water types of the western Tasman Sea: A stable isotope analysis. Deep-Sea Res Pt I. 104, 1, 2015.

36. CRESSON P., RUITTON S., FONTAINE M., HARMELIN-VIVIEN M. Spatio-temporal variation of suspended and sedimentary organic matter quality in the Bay of Marseilles (NW Mediterranean) assessed by biochemical and isotopic analyses. Mar. Pollut. Bull. 64, $1112,2012$.

37. VIZZINI S., MAZZOLA A. Stable isotope evidence for the environmental impact of a land-based fish farm in the western Mediterranean. Mar. Pollut. Bull. 49, 61, 2004.

38. HANNIDES C.C.S., ZERVOUDAKI S., FRANGOULIS C., LANGE M.A. Mesozooplankton stable isotope composition in Cyprus coastal waters and comparison with the Aegean Sea (eastern Mediterranean). Estuar Coast Shelf Sci. 154, 12, 2015.

39. VALLS M., OLIVAR M.P., FERNÁNDEZ DE PUELLES M.L., MOLÍ B., BERNAL A., SWEETING C.J. Trophic structure of mesopelagic fishes in the western Mediterranean based on stable isotopes of carbon and nitrogen. J. Mar. Syst. 2014.

40. PAPIOL V., CARTES J. E., FANELLI E., RUMOLO P. Food web structure and seasonality of slope megafauna in the NW Mediterranean elucidated by stable isotopes: Relationship with available food sources. Journal of Sea Research. 77, 53, 2013.

41. YILDIZ H., BERBER S., ACARLI S., VURAL P. Seasonal variation in the condition index, meat yield and biochemical composition of the flat oyster Ostrea edulis (Linnaeus, 1758) from the Seasonal variation in the condition index, meat yield and biochemical composition of the flat oyster Ostreae. Italian Journal of Animal Science. 10, 22, 2016. 